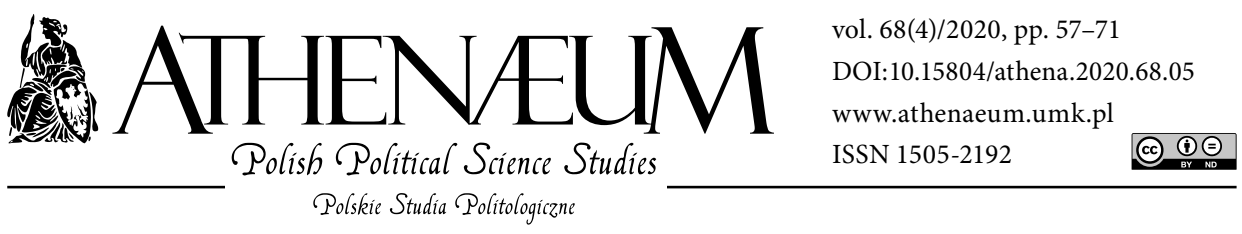

\title{
THE SECULARISM \\ OF MODERN POLITICAL SCIENCE RESEARCH: IS THE INTERPRETATIVE-EMPIRICAL ALLIANCE A POSSIBILITY?
}

\author{
SEKULARYZM WSPÓŁCZESNYCH BADAŃ \\ POLITOLOGICZNYCH. \\ CZY MOŻLIWY JEST ALIANS INTERPRETACYJNO- \\ -EMPIRYCZNY?
}

Łukasz Młyńczyk* (ㅇ

\begin{abstract}
Nowadays, we are eye-witnesses of the process which we shall refer to as the secularism of political science. Obviously, this concept can be construed in two ways. One is institutional secularism, which eliminates the influence of religion, or more broadly put - ideology, on the theoretical work of contemporary researchers. Such a viewpoint is imposed by the liberal discourse so we must be mindful of the fact that it is a viewpoint motivated ideologically. Such a perspective results not only in the separation of humanities from social science but also the ranking and positioning of scientific disciplines in the global knowledge circulation, exemplified by the Polish inclusion of religion into the category of science of culture under the new administrative division of scientific disciplines. The other one
\end{abstract}

Współcześnie obserwujemy proces, który określać będziemy sekularyzmem nauk o polityce. Oczywiście można to pojęcie rozumieć na dwa sposoby. Pierwszy to sekularyzm instytucjonalny, który w założeniu eliminuje wpływ religii, a szerzej ideologii, na przebieg teoretycznych ustaleń dzisiejszych badaczy. Ten punkt widzenia narzucany jest przez dyskurs liberalny, a więc nie powinno umknąć naszej uwadze, iż jest to stanowisko motywowane ideologicznie. Powyższe ujęcie ma konsekwencje nie tylko dla separacji humanities oraz social science, ale również w uszeregowaniu i pozycji dyscyplin naukowych w światowym obiegu wiedzy, czego polskim przykładem jest włączenie religii do nauk o kulturze według nowego administracyjnego podziału dyscyplin naukowych. Drugi sposób rozumienia pojęcia

* University of Zielona Góra, Institute of Political Science and Administration. 
can be denominated as scientific secularism, with its credo originating from logical positivism (logical empiricism), and it will be the reference point for the text of this article. Its effect is the demarcation focused on the exclusion of the theoretical content of political science research, which is often regarded as political philosophy in the English-language literature and speculation in Poland. The aim of this article is the meta-theoretical analysis of the political science research programme from the perspective of the features potentially linking the varied academic achievements and the inference methodology of contemporary political scientists.

Keywords: secularism of political science; political science research programme; interpretativeempirical approach; interpretationism; empirical approach określić możemy sekularyzmem naukowym, wywodzącym swoje credo $\mathrm{z}$ neopozytywizmu (empiryzmu logicznego), i ten będzie punktem odniesienie dla tekstu artykułu. Efektem jego stała się silna demarkacja, skoncentrowana na wyłączeniu pewnego obszaru teoretycznych badań politologicznych, które uznaje się często w anglosaskiej literaturze za filozofię polityczną (political philosophy), w Polsce zaś nadaje się im miano spekulacji. Celem artykułu jest metateoretyczna analiza programu badawczego politologii pod kątem cech potencjalnie łączących zróżnicowany dorobek i metody wnioskowania współczesnych politologów.

Słowa kluczowe: sekularyzm nauk o polityce; program badawczy politologii; podejście interpretacyjno-empiryczne; interpretacjonizm; empiryzm

\section{REMARKS ON THE SCIENTIFICITY OF POLITICAL SCIENCE}

The institutionalisation of political science research, first in the world, then in Poland, occurred so long ago that a discussion on the discipline's cognitive strategies is unnecessary. Obviously, we realize that the resultant of the assessment of institutional potential is its ability to introduce into the scientific thought circulation the research results which are subject to publication and intersubjective verification. The institutionally scientific goal comes down to the possibility of being recognised, that is, being present in the major scientific discourse of a given subdiscipline. Even if not at its very core, as close to the core as possible. It is also worth remembering that something that seems to be a common truism has recently achieved the status of an important argument, i.e., basing the research itself against the context of discovery and the context of substantiation. As far as the former is perceived by many as a non-orthodox circumstance, as it means a set of emotional states or the researcher's views personally impacting the discovery itself, the substantiation is rational procedures serving to accept or refute scientific theories (Heller, 2016, p. 140). We must remain aware of the overrepresentation of descriptive research in Polish political science, of a certain 
kind of rejecting behaviourism as a method of researching political science phenomena and processes. Further, aware of the strong interpretative trend in the Polish political science, which is somewhat unfairly regarded as speculative. The arguments against the latter appear to be serious as they come down to the externalisation of the results of particular investigation. In Poland, we have been raised on the humanities tradition which is partly a derivative of the selection of the achievements of political scientists from the achievements of historians, lawyers, philosophers and sociologists, while in practice it means putting a strong influence on the individual creative process, more characteristic of the broad and normative philosophical narrations. Without doubt, they are the carrier of the isolated scientific issues which are currently gaining the status of scientific ones only through their empirical verification. Obviously, we do not assume the existence of national political science, even though such contractual terms appear in the discourse, as we regard science as supranational by definition. At this stage, questioning the empirical order in political science would equal questioning the facts which are the obvious image of the dominant political science research in the contemporary scientific circulation globally. Thus, the situation is pursued where the given law (expressed with the $L$ clause) determines the ability to predict and account for a given social (political) phenomenon, while the mere ability to describe it is left at the pre-theoretical stage (e.g., taxonomy), where facts placement is performed in their descriptively construed specifics. Most likely, the place of research findings in the form of publication is not an argument par excellence scientific, yet it can be regarded as the sufficient condition, implicitly determining that scientific character, as the ability to evoke a scientific discourse (or citationality) makes the research noticeable in scientific circulation. Thus, even though it does not decide directly about the power of the evidence, it does fulfil the clause of the intersubjectivity of scientific theories. We must promptly signal our probable inability to conduct empirical evidence to support the scientific character of this argument. This arbitrary rationality is indeed a valuation derivative; that is, the confidence in having made the right choice, however non-rational according to its own assumptions. Obviously, it does not mean that it is not possible to prove the non-scientificity of the scientific rule itself, but merely marking the necessity for the existence of presuppositions resulting from the inability to escape valuation completely. In the practice of today's misunderstanding concerning the Polish specifics of humanities, political science to be precise, it would be about showing or prejudging what strictly scientific (empirically tested) acknowledging the achievements of humanities, 
including critical studies and interpretationism, as founded on the intuition of researchers, constitutes solely unjustified speculations, thus setting researchers in the realms of metaphysics.

Independently of the common assumption that hypotheses (scientific ideas) are created intuitively, Popper used the concept of "creative intuition", for it is impossible to reach for new ideas in the non-psychological way, i.e., performing the process by means of logical reasoning (Popper, 2002, p. 33). However, it does not mean that a part of Polish achievements in political science is regarded as non-disturbing in the mainstream research, the marginalisation of which is supposed to be indicative of the low level of congruence of a large group of domestic political scientists with the global scientific circulation. What is more, the problem does not lie in the language of the given publication as it remains unquestioned that the English language is the vehicle of human communication in the world of scientific research. However, the aim of this article is to determine the metafeatures of the interpretative-empirical approach as the effect of their dialectic context. The remarks formulated will refer to the properties of the epistemological political science. However, it is not only about the scheme under which the interpreted problems are subject to empirical verification as it creates a radical disproportion in the results of such findings. It seems to be more important to find the answer to the question of the possible complementary functioning of those two types of methodology. Considering solely the bibliometric indicators, there does not even exist a relative balance between the two. The choice of the cognitive strategy affects not only the sphere of procedures (substantiation), but it can be conditioned by the mental conviction of the adopted research approach (cognition). Incomplete enumerative induction compensates the researcher's initial doubts with the quantitativeness of the result. As much as the necessity of marking the features of the phenomena belonging to a given set of events may not appear very controversial, the investigation of the feature for particular cases itself is doubtful as it is impossible to investigate every single event. Certain generalisations are applied, which do not as much refer to the reinforced social laws based on the cause and effect relationship, but rather to those generalisations construed as the laws serving the given explanations, allowing the detection of regularities, thus - expressed with prediction (Sartori, 1997, pp. 30-31).

Hence, as rightly observed by Bartłomiej Michalak, statistical claims must not be regarded as laws - even though they allow detecting regularities, they do not have the explanatory power (Michalak, 2015, p. 49). Thus, we are talking about a finite number of cases which are subject to our judgment. Obviously, due to 
natural limitations investigating every single example may prove impossible. However, it does not have to result in absolute negation of such a strategy, for the fear of finding a single counter-example that will force us to discard the whole line of reasoning. This is where we are succoured by the category of "common sense" (sensus communis) where rational arguments (based on the accuracy of reasoning) must be cleaned of rhetorical elements. The allegation of the probable possibility to overturn the law without formal evidence is also based on rhetorical arguments; in some cases it may be largely less probable than the adopted law. In this context, special attention should be given to the eristic issues. This concerns the use of the term "theory" with the most classic example from the natural science, i.e., "evolution, which is said to be merely a theory" (Arsuaga, 2020, p. 50). The essence of the statement that something is theoretically probable is not about discretion and doubt but about giving it the clause of scientific character, for that "theoreticality" is a scientific explanation, obviously falling under empirical judgment (verification or falsification). In other words, the time in which the subsequent cumulating facts and data do not breach the given theory but allow claiming the theory itself is not radically false is regarded as the period during which it gains the status of a recognised theory (Arsuaga, 2020, p. 51).

However, this is always where fallibilism comes in, and scientific theories cannot be construed as dogmas. When applying the radical methodological view ensuing from the above we would have to regard the entirety of science as speculation and the realm of metaphysics. However, Popper's fallibilism, as interpreted by Lakatos, did not make strictly scientific the things that could be overthrown as the result of observation because facts could always overthrow "factual claims"; however, in practice, this did not have to mean questioning the law (Lakatos, 1995, pp. 22-23). As much as the colloquially perceived theoreticality of phenomena is associated by many with presumption, in scientific practice theory must possess features enabling the accounting for facts, regardless of the experience or sole intuition of researchers. Thus, the theoretical approach to the issue, as in the case of interpretationism, does not avoid empirical judgment. Not necessarily does it speculate about political phenomena and processes. Does it mean that theory checked against the facts of political science can be the same thing that it remains to be for contemporary physics? It is about the possibility to create measurement criteria analogical with theoretical physics, the representative of which shows empiricists what to look at.

The knowledge of political phenomena and processes, perceived as social science, remains an observation the result of which are measurements and codi- 
fications. However, 'empiricality' is not only the test of what is external as we still have control over the researched object. It is also no less important what Popper defined as "expectations horizon" (Popper, 2012, pp. 406-409). The questions asked represent our anticipation about what is the subject of the observation. Observation as a theory derivative is not conducted in an assumption-less manner. The observation's accompanying theoreticisation positions the researcher against the subject of research. The objectivised subjectivity, as the inductive reasoning into social (political) behaviours should be referred to, presumably has reductionist ambitions with regard to the acquired knowledge.

Falsificationism in its dogmatic version postulated the possibility of daring speculations, which were refuted and replaced with new ones by means of empirical tests (Lakatos, 1995, p. 13). It was assumed impossible to create an empirical database of scientific theories for their confirmation. In effect, no one could negate what was speculative exclusively for formal reasons (no test) because, against the expectations of empiricists, facts do not prove postulates. Nevertheless, in the critical reception of dogmatic falsificationism it was pointed to the lack of the analogical reliability in refuting theories due to the doubts arising from observations (Lakatos, 1995, pp. 18-22). Thus, Lakatos notes that, according to the assumptions of dogmatic falsificationists, scientific theories can neither be proved nor refuted. Meanwhile, the refined methodological falsificationism assumed that theories cannot be simply "killed" with falsification tests if we have arguments in the form of creating auxiliary hypotheses and reinterpreting the terms of theories, however not using "linguistic tricks" (1995, pp. 46-47). Wojciech Sady argues that the results of the observation of experiments cannot defy theories, for "observation" [quotation marks by W.S.] clauses are not the result of theorized experience and do not result straight from the theory itself, hence the attempts of cyclically accounting for "troublesome facts" (anomalies) and creating auxiliary hypotheses (Sady, 2000a, p. 138). This brings us back to the reality in which the language describing political phenomena not only serves as the tool for formulating research hypotheses but also represents the concept of justifying the observations made by political scientists. However, although it described the reality available empirically, it did not use the hypothetical-deduction method. Thus, theories created in this way were not strictly scientific; however, they remained within its jurisdiction. In the reality researched by political science there are theoretical descriptions which can be attributed with features that are similar to axioms; however, their existence in the scientific circulation did not result in categorical rebuttal which can be regarded 
as a tool for effective representation of the state through a set of ideas. Hence, negating them on the basis of formal defects will be an arbitrary decision. It is not true that humanist researchers do not use arguments in their substantiations, while taking care of their hierarchy and non-contradiction (Węsierski, 2011, pp. 96-97). It is particularly prominent in research on international relations, starting from realism, with particular inclusion of the Thucydides trap, later evolving into neorealism or structural realism with the aim of finding theories that are less philosophical and more scientific (Korab-Karpowicz, 2017). At this point, there occurs a doubt concerning the linear continuation of political science knowledge, i.e., a standpoint against the general assumptions of the scientific revolution by Thomas S. Kuhn. The significant components of the previous paradigms by Kuhn were destructed; however, this process was also accompanied by the constructive effect (Kuhn, 2009, p. 123). The theory and philosophy of politics uses concepts which at present remain in the "post-" phase or the "neo-" state. Hence, it is worth considering whether that state means questioning the previous meaning. The positive answer depends on our own conviction rather than the empirical evidence that the linear increase in knowledge about social reality makes the previous concepts out-of-date in their previous specifics. We commonly acknowledge the constancy of natural conditions for as much as the values describing the state of the nature change, its uncovered properties are defined as analogical in time. The social environment recognised through the participation of the observer himself forces him to formulate precise conclusions; however, in terms of political science, not only do we deal with its development but also the intangible property in the time measurement unit. Social phenomena and processes possess internal dynamics; therefore, research must be correlated with their essential evolution. It is dependent not only on the changing database of social concepts but also the parallel evolution of human relations themselves with science trying to meet that challenge. However relatively easy it is to point to the lack of verifiability of such type of knowledge from the strictly empirical standpoints, the interpretative-conceptual model is still being used in the political science analyses of social and international relations. Without expressing doubt in the empirical value of the scientific evidence it is worth noting that the concepts applied in numerous political science analyses are a durable set of evaluations and descriptions of political phenomena and processes the veracity of which is, essentially, not questioned, making it the source of thinking about politics. However, scientific interpretation in political science is a different type of reasoning than the journalistic speculation. The latter explicitly creates 
(postulates) phenomena, employing the oversimplified description of reality. One of the aims of science is making predictions. Its effectiveness depends on the forecast basis. In natural science, theoretical assumptions gain scientific character through logical reasoning due to employing mathematics as the formal language of physics.

In social science we use the natural (ethnic) language, imprecise in its description for it is rooted not only in communication sensu stricto but also sensu largo, where it is an element of the language of culture or theology (Ossowski, 2001, p. 189). Another issue is the transfer of the meanings of traditional concepts which are given false designates, thus creating new phraseological collocations. In such an event, political scientist-empiricists take advantage of statistical research; however, the generalisations thus created do not allow formulating universal explanations when the former only serve detecting irregularities. Therefore, it is not possible to disregard the scientific language as a system of signs. The postulated precision of political behaviours measurement must be accompanied with a description which by its nature remains imprecise for it carries with it a certain ambiguity; however, it can be also regarded as its asset as it leaves room for intuition and interpretation (Węsierski, 2011, p. 29). The essence of scientific research, including social science, is in proving the cause-effect relationship. Thus, is political science capable of generating a certain kind of universal laws that would not be generalisations based on exceptional properties in time and space (Sułek, 1979, p. 25)? The empirical approach regards the "behaviours" category as a dependant variable, and in the narrower political sense it can also be defined as "action". Experiment has the basic cognitive value; however, this label was also attached to all the actions that failed to have the predicted effect and still pursued a social change the cause of which was the previously defined problem (practical goal) (Sułek, 1979, p. 16).

When appealing to the three worlds theory, Popper ruled out the practical use of knowledge in the field of social science in solving social problems (Grobler, 2016, p. 152). It does not mean that he considered social problems insignificant, it means that when determining the strong imperative for science demarcation he did not place social research in the realm of science. Political science knowledge, derived from empirical measurements, has the cognitive aim; however, it can also be used to change social behaviour, but it is a cumulative effect rather than theological. Of identical status are the theories for interpreting reality; however, they are more strongly subjected to modification. Conclusions deduction in relation to political features assumed the recognition of the adequacy of politi- 
cal action types. It is of exceptional significance in the context of marking the features of particular political discourses, conditioned ideologically. In such an event, the dominance of the liberal discourse also left its mark on the cognitive processes of political science. The creation of the image of the individual as the demiurge allowed deducing social, political or economic relationships, whereby the scientific value must assume the constant liaison between the will of the individual and the political model pursued by the society made up of such individuals (Milbank, 2019).

Thus, we had not only the secularism of science as a result of departing from metaphysics, but also the pragmatic treatment of the secularisation of sociocultural relationships, an element of which science still remained. This treatment can be placed in the broader perspective of de-ideologization of science with the purpose of rejecting judgments regarded as doctrinarian. An indirect effect of the empirical paradigm of social science is researching what one partially evokes. One is looking to lend credence to the assumptions which change the existing world at the time of their disclosure. Interpreting and researching political behaviours differ from each other with the level of the agent's intervention in the subject of the research. We must bear in mind that every action is goal orientated. The political theorist and political practitioner (politician) both set goals and pursue to achieve them. The goal set by the theorist does not have to be achieved; however, it often happens that those goals are set nolens volens. Thus, there are the theorists who design goals, and practitioners who think of measure for achieving them; however, the very theoretical thought of politics is more significant in formulating general goals than particularist goals (Graham, $1999 \mathrm{~b}$, p. 4). Hence, is it wrong to claim that, for instance, the theorist interpreting the political reality is inferring, not speculating, about the implementation of interests? As a consequence, the category of implementing political interests is used in empirical research as an effect of theoretical inference as in political science there exist terms which in the methodological sense could be regarded as primal, such as "power", thus not subject of further definition. In principle, we could use terms to define them but we consciously do not do that as we need concepts for the theoretical description of the researched problem.

After all, the specifics of the above-mentioned concepts does not make all political science analyses speculative, and the language of scientific communication must base upon reinforced codes which are often not the effect of empirical tests. Obviously, encoding data for measuring political behaviours uses the concepts about the meaning of which a common consensus exists. The encoding 
process itself is not in contradiction with the interpretative property of theories, in principle being an intuitive description of the observations by the statistical (numerical) element. Hence, it is not always the case that empirical research is of a higher substantiation value as it can be identical as the theoretical description in illustrating the problem. However, predicting future events in politics enforcing taking account of a number of process participants and a long period of time, decisions content and their implementation, is threatened with a high risk of failing to achieve the result when stretching the "chain of actions" (Graham, 1999b, p. 9). Then, our prediction achievements can be limited significantly.

We should also mention the postulated direction of political science research which locates our discipline in the area of the copy of social psychology. The practical result of this phenomenon is selectively regarding a part of political science research as fully scientific. There arises the question whether the reductionist political science analysis employs all available possibilities of describing, substantiating and predicting political phenomena and processes. At the same time, it must be considered whether the theory of political science, not actually being normative philosophy, describes the world primarily in aesthetic and emotional categories, avoiding giving the scientific character to the inference. According to perceptual experience, the basis of empirical social research, the knowledge about facts is derived from our sensations (Popper, 2002, p. 81). From this arises the reflection on the ability of political science to substantiate the theorems generated by our inference. Experiments in social science and behaviours observation cannot be substantiated through logic; instead, they focus on observations and sensations, i.e., psychology categories. As a consequence, when researching phenomena defined as political ones we, in a way, state something at the cost of substantiation. The observation itself is of remarkably lower cognitive value than scientific theory, which is subject to empirical testing (Jodkowski, 2013, p. 66). In principle, it is not changed by the fact that we can numerically encode the values of observation in such a way that they become measurable.

Jodkowski is right in pointing to the fact that more accurate theories cannot be drawn from less accurate observations; thus, the road of inductionism is not a strategy without alternatives to political scientists. Nowadays, political scientists are too much attached to the time over which their research (observation or experiment) is conducted, believing that the knowledge accumulated hic et nunc accounts for the actual processes and predicts future trends. As indicated before, statistical laws allow detecting regularities but they cannot be used for making explanations. Thus, the scientific clause is incomplete for this type of political 
science research. The conclusions drawn on this ground, although referring to the proposed explanatory theory, are of scientific nature mainly on the postulative basis.

Nowadays, in political science what we deal with is ignoring theorists by empiricists which is to the disadvantage of our discipline. In the currently developing sciences, to which without doubt political science aspires, there is the pursuit of the permeation of theories and experience in order to improve the empirical method, in consequence improving the value of the theory itself. Obviously, the role of the observer in social science is no less important than in natural science, and taking into account the inability to separate the observer from political phenomena and process the problem only gains additional carrying capacity. At this point, the shared problem of physics and political science can be the fundamental for philosophy of science judging whether the property being measured by us does exist at the time of measurement (Heller, 2016, p. 73), or are we merely the originators of its revelation.

Alas, at this point we must carry out separation of the above-mentioned sciences for in political science there are theories, often denominated as political philosophy, the value of which is not so much subject to empirical verification as utter rebuttal due to their apriorism. As being unfounded on empirical research, they are negated for being based on the sensual perception of the observer rather than the quantifiable opinions of the research objects. As regards the latter, it is consciously ignored that they use the description of sensual perceptions. Hence, the lack of correlation between the above-mentioned approaches is a peculiar kind of waste. Nevertheless, under the universal approach to science demarcation, theories are general in terms of time and space; hence, they cannot be proven empirically (Sady, 2000b, p. 164). In political science, empirical tests are actually condition sine qua non of qualifying a text as a scientific one. This is accompanied by a specific certainty in the subject of the scientific value of such an approach.

A lot of emphasis is put on the selection and quality of the cases to be verified; however, it must be noted that increasing the accuracy of measurement through testing a great number of cases sounds like the not always effective promise of Bayesianism. Political science offers historical generalisations, statistical generalisations, or qualitative theorems. The former, essentially formulated as general statements, can be partially qualified as speculations as they do not come under strict empirical verification while being applied to with the reasoning principles (scientific empathy). To Popper, statistical laws are also not ultimate, 
nor confirmable, nor refutable (Węsierski, 2011, p. 93). When it comes to political science, the discourse is between the aprioristic adoption of axiological theories and the arbitrary conviction about the convergence of base statements with the reality by means of empiricism. One could think about the dialectic approach to the issue. Thus, are theories lacking in scientific proof a cognitive usurpation? No, if we come to realize that in the political science circulation of those we shall not find theories utterly confirmed or utterly falsified. Whereby, testing theories in political science is not performed in theory-cognitive sterility for a great number of assumptions constitute logical or axiological reasoning which is not subject of empirical testing.

From the standpoint of scientific humanities, the ability to interpret complex phenomena and process on the basis of the previous findings of political ideas and theories is a reward for those undertaking such endeavours. However, there is also a third standpoint, based on the conviction that what is of scientific nature is determined by means of the rules of deduction. Thus, in keeping with Popper, we are questioning the irrational conviction that the majority cannot be wrong. Obviously, to contemporary political science induction is, to a certain extent, an optimal choice, particularly in the wake of the lack of objectively universal laws of social science, political science in particular. The fundamental weakness of political science as a discipline of social sciences, with regard to the assumptions of the theory of science made by Karl R. Popper, could be its forced absence in the three worlds theory (Popper, 2012, pp. 138-161). Scientificity construed in this way also rules out political science, but it is all primarily about a certain kind of scientific debility of social research. It is manifested by the inability to use the knowledge of social science in attempting to solve social problems - let us be mindful that Popper's theory excludes the social world. Deducing isolated statements from general statements is a universal scientific strategy. In other words, what is deduced is predictions - empirical conclusions (Popper, 2002, p. 33). Jerzy Kmita distinguished the linguistically dependent scientific substantiations, the strength of which was the temporarily accepted rules of public argumentation as serving through interpretation and prediction control of our physical environment, and the humanistic interpretation as the expression of the imitative experience (Kmita, 2000, p. 52). Thus, we are faced with an illusory theory-cognitive choice. Empathy as the expression of impersonating the researched object, even though it ignores the aspect of "giving the floor to the researched", is oriented towards behaviour (action or inaction). 
The traditional political science was regarded as descriptive rather than explanatory. In the first half of the $20^{\text {th }}$ century, the theorists of political science represented the imperative of the investigation based on the necessity to recreate the process-event relationship. Nevertheless, the identification of politics with the feature of exercising power led to the secondary identification of political system features and formal structures at the cost of accounting for political processes and behaviours (Buttolph-Johnson, Reynolds, \& Mycoff, 2010, p. 63). The then contemporary political scientists tried to substantiate their theories. It was oral substantiation, often very well thought-out and orderly. However, it was not the mathematical-empirical model, i.e., one that we consider to be rational, even though we regard it as normative as principally indisputable but still a value. Meanwhile, Michał Heller argues that the boundaries of the mathematicalempirical method define the scientific (rational) framework only when we decide that the problems going beyond its formal possibilities are non-scientific (irrational) (Heller, 2014, p. 7).

Following the road taken by contemporary social science, which remains under strong influence of the methodological orientation of psychologists, we can assume that researching political behaviours is correct (well-grounded). Regardless of what preliminarily forejudges the qualification of this phenomenon as political. It seems that all electoral behaviours can, in principle, prescind from being and not being political, focusing attention on lending credibility to the research in the form of the postulated discovery of social law. Especially through their potential to apply the mathematical-empirical method. This is not accompanied by the cognitive universality of natural science. Every single political behaviour can be described in a multiple number of ways, taking into account the extended contexts. At this point, the following question could be asked: do findings like that only signify that we managed to come up with a regularity ("patterns happen")? As much as empirical measurement can serve as the confirmation of this interpretation, there is no formal agreement about the equality of evidence "without evidence". Social laws are strongly correlated with time and space which decide about their explanatory function. Thus, the arbitrariness of social issues depends principally on the belongingness to a particular paradigm construed temporally and geographically. The context seems to be important as we are prone to using familiar criteria which are the function of the conducted observations. The social and political reality is observed through established expectations (theorisation) or an image of conditions which we consider universal where the conclusion belongs in a simplified (i.e., obvious) way 
to the identified context (Taleb, 2013, pp. 58-59). Our observations of political phenomena, intuitively close to us as they usually concern us to a certain extent, lead to conclusions which are the very result of those observations.

\section{ReFERENCES:}

Arsuaga, J.L. (2020). Życie. Fascynująca podróż przez 4 miliardy lat. Kraków: Znak.

Buttolph-Johnson, J., Reynolds, H.T., \& Mycoff, J.D. (2010). Metody badawcze w naukach politycznych. Warszawa: Wydawnictwo Naukowe PWN.

Denzin, N.K., \& Lincoln, Y.S. (2009). Metody badań jakościowych. Vol. 1. Warszawa: Wydawnictwo Naukowe PWN.

Frankfort-Nachmias, Ch., \& Nachmias, D. (2001). Metody badawcze w naukach społecznych. Poznań: Zysk i S-ka.

Gazzaniga, M.S. (2017). Po obu stronach mózgu. Moja przygoda z neuronaukiq̨. Kraków: Copernicus Center Press.

Graham, G. (1999a). Political Theory and Political Practice. Journal of Applied Philosophy, 16(2), 113-121. DOI: 10.1111/1468-5930.00114.

Graham, G. (1999b). Political Theory and Political Practice. Retrieved from: https:// www.academia.edu/2907060/Political_Theory_and_Political_Practice?email_ work_card=thumbnail.

Grobler, A. (2016). Dwa pojęcia wiedzy: w stronę unifikacji. Przegląd Filozoficzny Nowa Seria, 25(1), 141-160.

Heller, M. (2014). Granice nauki. Kraków: Copernicus Center Press.

Heller, M. (2016). Filozofia nauki. Kraków: Copernicus Center Press.

Heller, M., \& Krajewski, S. (2014). Czy fizyka i matematyka to nauki humanistyczne? Kraków: Copernicus Center Press.

Hossenfelder, S. (2019). Zagubione w matematyce. Fizyka w pułapce piękna. Kraków: Copernicus Center Press.

Jodkowski, K. (2013). Nienaukowy fundament nauki. In: Z. Pietrzak (ed.). Lectiones \& Acroases Philosophicae, 6(1): Granice nauki, 59-106.

Kmita, J. (2000). Wymykanie się uniwersaliom. Warszawa: Oficyna Naukowa.

Korab-Karpowicz, J.W. (2017, May 24). Political Realism in International Relations. Stanford Encyclopedia of Philosophy. Retrieved from: https://plato.stanford.edu/ entries/realism-intl-relations/.

Kuhn, T.S. (2009). Struktura rewolucji naukowych. Warszawa: Wydawnictwo Aletheia. Lakatos, I. (1995). Pisma z filozofii nauk empirycznych. Warszawa: Wydawnictwo Naukowe PWN.

Michalak, B. (2015). Czy prawa Duvergera nadal obowiązują? Studia Socjologiczne, 3, 41-64.

Milbank, J. (2019). John Milbank: Teologia i pozytywizm. Retrieved from: https:// teologiapolityczna.pl/john-milbank-teologia-i-pozytywizm. 
Ossowski, S. (2001). O osobliwościach nauk społecznych. Warszawa: PWN.

Popper, K.R. (2002). Logika odkrycia naukowego. Warszawa: PWN.

Popper, K.R. (2012). Wiedza obiektywna. Ewolucyjna teoria epistemologiczna. Warszawa: PWN.

Sady, W. (2000a). Fleck. O społecznej naturze poznania. Warszawa: Prószyński i S-ka.

Sady, W. (2000b). Spór o racjonalność naukową. Od Poincarégo do Laudana. Wrocław: Monografie Fundacji na Rzecz Nauki Polskiej.

Sartori, G. (1997). Comparative Constitutional Engineering: An Inquiry into Structures, Incentives and Outcomes ( $2^{\text {nd }}$ ed.). Basingstoke, Hampshire: Palgrave Macmillan.

Sułek, A. (1979). Eksperyment w badaniach społecznych. Warszawa: Państwowe Wydawnictwo Naukowe.

Taleb, N.N. (2013). Antykruchość. O rzeczach, którym służą wstrząsy. Warszawa: Kurhaus Publishing.

Węsierski, M.R. (2011). Problemy integracji wiedzy a badanie zjawisk politycznych. W stronę idei jedności nauki. Warszawa: Semper. 